\begin{tabular}{c} 
PEDIOMATERNAL \\
NURSING JOURNAL \\
Vol. 5, No. 2, September 2019 \\
Journal Homepage: https://e-journal.unair.ac.id/PMNJ// \\
\hline
\end{tabular}

Original Research

\title{
Hubungan Antara Penggunaan Kontrasepsi Implan dengan Komunikasi, Informasi, Edukasi (KIE), dan Pengetahuan
}

\section{(Relationship Between Use of Implant Contraception with Education Information Communication (EIC), and Knowledge)}

\author{
Nurul Alfiyah ${ }^{1}$, Djohar Nuswantoro ${ }^{2}$, dan Sunarsih ${ }^{3}$ \\ ${ }^{1}$ Program Studi Kebidanan, Fakultas Kedokteran Universitas Airlangga, Indonesia \\ 2 Departemen IKM-KP, Fakultas Kedokteran, Universitas Airlangga, Indonesia \\ ${ }^{3}$ Politeknik Kesehatan Kementerian Kesehatan Surabaya, Indonesia
}

\section{ARTICLE HISTORY \\ Received: May 24, 2019 \\ Accepted: Aug 27, 2019}

\section{KEYWORDS}

effectiveness; education information communication; implant; perception

\section{CORRESPONDING AUTHOR}

Nurul Alfiyah nurulalfiyah06@gmail.com Program Studi Kebidanan, Fakultas Kedokteran Universitas Airlangga, Indonesia

Cite this as:

\begin{abstract}
Introduction: Contraception usage in Indonesia had not effective yet. The high usage of contraception not compensated by evenness on each type of contraception. Implant as a long acting reversible contraception with high effectiveness is rarely used because of negative perception in society. The existence of negative perception caused by lack of information and knowledge about implant contraception. The study analysed association between implant contraception usage with Education Information Communication (EIC) and knowledge.
\end{abstract}

Methods: An observational analytic with a case control design. The population were 822 contraceptive acceptors. Study period on January-December 2018. Total samples were 70 with a sampling technique using purposive sampling. Divided into 2 groups, (35 nonimplant acceptors as a case group and 35 implant acceptors as a control group). Data obtained through primary data and obtained from the results of guided interviews and questionnaires. Then analyzed through the chi square statistical test.

Results: $60 \%$ of acceptors got a good EIC about implant contraception $(p=0.001), 51.4 \%$ of acceptors had enough knowledge about implant contraception ( $p=0.94)$.

Conclusion: There is an association between EIC with implant contraception usage, but there isn't an association between knowledge of implant contraception usage.

Alfiyah, N., Nuswastoro, D., \& Surnarsih. (2019). Hubungan Antara Penggunaan Kontrasepsi Implan dengan Komunikasi, Informasi, Edukasi (KIE), dan Pengetahuan. Pediomaternal Nurs. J., 5(2), 152-157.

\section{PENDAHULUAN}

Indonesia merupakan negara berkembang dengan jumlah penduduk yaitu sekitar 258 juta jiwa, hal ini tercatat dalam profil kesehatan Indonesia tahun 2016 berdasarakan perhitungan yang dilakukan oleh Pusat Data dan Informasi Kementerian Kesehatan RI (1). Jumlah penduduk yang terus meningkat ini dikarenakan laju pertumbuhan penduduk yang tinggi. Permasalahan pada pelaksanaan program Keluarga Berencana sering disebut-sebut sebagai faktor utama meningkatnya laju pertumbuhan penduduk Indonesia (2).

Berdasarkan data SDKI 2012 bila dibandingkan dengan RPJMN (Rencana Pembangunan Jangka Menengah Nasional) 2014-2019 dapat dilihat bahwa angka CPR Indonesia telah melampaui target $(60,1 \%)$ dengan capaian $61,9 \%$ namun angka TFR masih berada dibawah target $(2,36 \%)$ yaitu $(2,6 \%)$ (3). Meskipun angka penggunaan kontrasepsi tinggi namun angka kelahiran menunjukkan dibawah target, hal ini dapat diartikan bahwa dalam 
penggunaan kontrasepsi masih belum menunjukkan keefektifan (4).

Tingginya angka penggunaan kontrasepsi tidak diimbangi dengan kemerataan pada ssetiap metode kontrasepsi yang ada (5). Pada kontrasepsi dengan metode jangka panjang (MKJP) jenis atau alat kontrasepsi yang paling dominan digunakan oleh wanita usia subur adalah IUD/AKDR, padahal metode kontrasepsi MKJP seperti implan juga memiliki efektifitas yang tinggi dan cukup efisien (6). Pemakaian implan di Propinsi Jawa Timur pada tahun 2012 sebesar 4,95\% dan angka tersebut masih berada di bawah angka nasional yatu sebesar 5,70\%. Kontrasepsi implan dinilai sebagai kontrasepsi yang efektif dari segi kegunaan dan biaya dengan tingkat keberhasilan mencapai 99\% (7). Kontrasepsi implan juga memiliki beberapa kelebihan, salah satunya yaitu tidak mengganggu kenyamanan saat bersenggama $(8,9)$. Meskipun implan memiliki beberapa kelebihan dan efektifitas yang tinggi, namun dalam penggunaannya masih sangat jarang diminati (10). Berdasarkan data Dinas Kesehatan Kota Surabaya pada tahun 2016, Puskesmas Ngagel Rejo yang berada di Kecamatan Wonokromo memilki cakupan KB Baru Implan yang banyak, yaitu 108 Akseptor atau $13,14 \%$ dari seluruh jumlah akseptor MKJP

Ada beberapa faktor yang mempengaruhi wanita usia subur dalam menentukan jenis kontrasepsi, begitu juga dengan pemilihan kontrasepsi implan (11). Berdasarkan studi sebelumnya rendahnya penggunaan implan salah satunya disebabkan karena rasa takut akan tindakan atau prosedur pemasangan kontrasepsi implan yang dinilai cukup menyakitkan. Persepsi tersebut muncul dikarenakan kurangnya Komunikasi Informasi Edukasi (KIE) yang benar dan tepat tentang implan itu sendiri (12). Dalam pemberian informasi sangat diperlukan sebuah media komunikasi untuk memperjelas KIE yang diberikan untuk mencegah timbulnya persepsi yang salah pada calon akseptor. Diluar faktor-faktor lain yang sudah ada, pengetahuan juga ikut berperan penting dalam perilaku seseorang untuk menentukan sebuah keputusan (13).

Berdasarkan data Dinas Kesehatan Kota Surabaya pada tahun 2016, Puskesmas Ngagel Rejo yang berada di Kecamatan Wonokromo memilki cakupan KB Baru Implan yang banyak, yaitu 108 Akseptor atau 13,14\% dari seluruh jumlah akseptor MKJP (14). Berdasarkan latar belakang tersebut penelitian yang dilakukan bertujuan untuk mengetahui hubungan antara penggunaan kontrasepsi implan dengan Komunikasi Informasi Edukasi (KIE) dan pengetahuan di Puskesmas Ngagel Rejo.

\section{METODE}

\subsection{Desain}

Penelitian ini menggunakan rancangan analitik observasional dalam bentuk case control. Kelompok kontrol adalah akseptor KB implan, sedangkan kelompok kasus adalah akseptor non-implan.

\subsection{Populasi, sampel, dan sampling}

Populasi yang digunakan dalam penelitian ini adalah seluruh akseptor kontrasepsi di wilayah kerja Puskesmas Ngagel Rejo pada periode tertentu sebanyak 822 akseptor. Besar sampel diperoleh dari perhitungan rumus besar sampel (analisis kategori tidak berpasangan), yaitu sebesar 35 sampel dengan perbandingan 1:1 pada kelompok kasus dan kelompok kontrol. Sehingga didapatkan 70 sampel keseluruhan dengan teknik pengambilan sampel purposive sampling.

\subsection{Variabel}

Variabel pada penelitian ini meliputi variabel independent atau variabel bebas yaitu KIE yang pernah didapatkan dari tenaga kesehatan menurut asumsi akseptor dan pengetahuan akseptor tentang kontrasepsi implan. Sedangkan variabel dependent atau varabel terikat yang digunakan untuk menggambarkan masalah penelitian adalah penggunaan kontrasepsi implan.

\subsection{Instrumen}

Instrumen yang digunakan pada penelitian ini adalah alat ukur pengetahuan berupa lembar kuesioner yang berisi pertanyaan tertutup. Daftar pertanyaan terdiri dari 25 pertanyaan tertutup dengan pilihan jawaban benar-salah seputar pengetahuan tentang kontrasepsi implan dan 13 pertanyaan tentang KIE yang pernah didapatkan dari tenaga kesehatan menurut asumsi responden. Pengetahuan dikatakan baik apabila jawaban mencapai $\geq 76-100 \%$ benar, dikatakan pengetahuan cukup apabila jawaban mnecapai $60-75 \%$ benar, dikatakan pengetahuan kurang jika jawaban mencapai $<60 \%$ benar. KIE yang didapatkan dikatakan baik jika 51-100\% jawaban menunjukkan KIE yang didapat jelas, dikatakan KIE cukup jika 0-50\% jawaban menunjukkan KIE yang didapat jelas. Kuesioner ini telah dilakukan uji validitas dan reabilitas pada 20 orang diluar sampel penelitian dan diolah menggunakan software SPSS 16.0. Untuk uji validitas menggunakan uji Pearson dengan hasil setiap item pertanyaan nilainya $>r$ table yang artinya valid, sedangkan untuk uji rebilitas menggunakan uji alfa cronbach.

\subsection{Prosedur}

Penelitian terlebih dahulu dilakukan dengan meminta permohonan izin pada pihak terkait. Kemudian dilakukan penentuan sampel yang sesuai dengan kriteria melalui buku register KB atau rekam medis puskesmas. Pengumpulan data untuk akseptor non implan dilakukan di Puskesmas Ngagel Rejo atau pada kegiatan posyandu yang diadakan oleh Puskesmas dan melalui bantuan kader yang dilanjutkan dengan kunjungan rumah. Untuk akseptor implan pengumpulan data dilakukan dengan kunjungan rumah berdasarkan data yang diperoleh dari Puskesmas ataupun dari kader 
setempat. Sebelum melakukan pengumpulan data dari responden, dijelaskan terlebih dahulu tujuan dari penelitian dan membagikan lembar informed consent yang kemudian dilanjutkan dengan membagika lembar kuesioner pada responden yang bersedia.

\subsection{Analisis}

Analisis data pada penelitian ini meliputi analisis univariat yang digunakan untuk menjabarkan secara deskriptif mengenai distribusi frekuensi, yaitu usia, pekerjaan, tingkat pendidikan, paritas, dan jenis kontrasepsi akseptor non-implan. Sedangkan untuk analisis bivariat digunakan untuk mencari hubungan antara penggunaan kontrasepsi implan dengan KIE dan pengetahuan melalui uji statistik Chi-Square dengan $\alpha=0,05$

\subsection{Ethical Clearance}

Ethical clearance terdiri dari informed consent, anonymity, dan kerahasiaan. Semua data dari responden dijamin kerahasiannya oleh peneliti. Penelitian ini telah mendapatkan kelaikan etik dari Komite Etik Penelitian Kesehtana FakultasKedokteran Universitas Airlangga Surabaya dengan nomor surat 306/EC/KEPK/FKUA/2018.

\section{Hasil}

Berdasarkan [tabel 1] menunjukkan bahwa setengah dari jumlah responden (50\%) berusia 20-35 tahun, sedangkan hanya 1 responden $(1,4 \%)$ berusia $<20$ tahun, sebagian besar responden $(62,9 \%)$ merupakan pendidikan menengah, sebagian besar $(65,7 \%)$ responden tidak bekerja atau sebagai ibu rumah tangga, dan responden yang memilki 2-4 anak sebesar 64,3\%.

Pada [tabel 2] dapat dilihat bahwa hampir seluruh (80\%) kelompok responden yang menggunakan implan pernah mendapatkan KIE tentang implan dari bidan atau tenaga kesehatan dengan baik dan sebagian besar $(51,4 \%)$ baik kelompok responden yang menggunakan implan maupun yang tidak menggunakan implan memiliki pengetahuan cukup tentang implan. Hasil analisis chi square untuk mengetahui perbedaan hungan penggunaan implan pada tiap variabel bebas. Variabel yang berhubungan dengan penggunaan kontrasepsi implan adalah KIE atau Komunikasi Informasi Edukasi dari tenaga kesehatan. Proporsi penggunaan implan pada kelompok respoden yang pernah mendapatkan KIE dari tenaga kesehatan dengan baik lebih besar dibandingkan dengan responden yang pernah mendapatkan KIE dengan cukup maupun kurang, yaitu masing-masing sebesar $80 \%, 17.1 \%, 2.9 \%(\mathrm{p}=0,001)$. Sedangkan untuk variabel pengetahuan sendiri tidak berhubungan dengan penggunaan implan, hal ini dapat diketahui bahwa sebagian besar responden yang menggunakan implan memilki pengetahuan yang cukup, yaitu $51.4 \%(p=0,94)$ Sumba Timur.

\section{PEMBAHASAN}

Hasil penelitian menyimpulkan bahwa bidan atau tenaga kesehatan telah memberikan KIE tentang implan kepada setiap calon akseptor yang datang ke Puskesmas, hal ini ditunjukkan dengan sebagian besar $(60 \%)$ responden pernah mendapatkan KIE dari bidan atau tenaga kesehatan dengan baik. Menurut Saifuddin (2010) KIE (Komunikasi, Informasi, Edukasi) sebagai salah satu komponen operasional yang strategis dalam program KB nasional mempunyai fungsi dan peranan penting guna meningkatkan dan memantapkan penerimaan masyarakat khususnya tentang KB dan kesehatan reproduksi (15).

Hasil penelitian juga menunjukkan bahwa dari total responden yang mendapatkan KIE dengan baik sebagian besar merupakan akseptor implan, yaitu sebesar 67\%. Pratiwi, (2013) berpendapat bahwa model komunikasi yang dilakukan dalam bidang kesehatan adalah komunikasi persuasif yanag terdiri dari beberapa pendekatan dan salah satunya adalah pendekatan kognitif (16).

Pada umumnya bidan atau tenaga kesehatan memberikan KIE sesuai dengan kebutuhan akseptor. KIE yang diberikan biasanya bersifat interpersonal atau individu. Calon akseptor akan diberikan informasi dan edukasi secara langsung tentang beberapa pilihan kontrasepai (informed choice) yang tujuannya adalah untuk mempengaruhi individu, sehingga nantinya calon akseptor dapat membuat keputusan untuk memilih jenis kontrasepsi yang sesuai dengan kebutuhannya yang dinyataakan dalam informed consent.

Hasil analisis penelitian didapatkan nilai $p=$ $0,001(p<0,05)$ yang berarti terdapat hubungan yang positif antara KIE dengan penggunaan kontrasepsi implan, dimana seakin jelas KIE tentang kontrasepsi implan yang didapatkan maka akan mempengaruhi seseorang menggunakan kontrasepsi implan. Perhitungan statistik untuk perbandingan antara KIE baik dan tidak mendapatkan KIE diperoleh OR 22,0 CI 95\% (2,575-187,979). Dari nilai OR dapat disimpulkan bahwa akseptor yang pernah mendapatkan KIE dengan baik tentang kontrasepsi implan akan memilih untuk menggunakan implan sebanyak 22 kali lipat lebih besar daripada akseptor non implan yang tidak mendapatkan KIE. Hal ini sejalan dengan penelitian yang dilakukan oleh Ellawela, (2017) tentang kebutuhan pelayanan kontrasepsi yang dilakukan pada populasi imigran Sri Lankan di Australia bahwa rendahnya penggunaan kontrasepsi yang memilki efektifitas tinggi, disebabkan presepsi yang salah tentang kotrasepsi tersebut karenan kurangnya informasi yang tepat dan baik dari tenaga kesehatan (17).

Namun, hasil ini bertolak belakang dengan penelitian yang dilakukan oleh Imroni, (2009) tentang faktor-faktor yang berhubungan dengan penggunaan implan di Desa Parit Kecamatan Indralaya, mereka berpendapat bahwa tidak ada hubungan antara pelayanan konseling KB terhadap 
penggunaan implan. karena meskipun bidan atau tenaga kesehatan telah memberikan KIE tentang kontrasepsi, tetapi keputusan pemilihan dan penggunaan alat kontrasepsi tergantung pada akseptor (18). Penelitian lain berpendapat bahwa rendahnya penggunaan kontrasepsi implan dikarenakan kurangnya informasi dari tenaga kesehatan. Konseling atau informasi yang diberikan hanya melalui lisan, sehingga informasi yang didapatkan kurang efektif dan memungkinkan timbulnya persepsi yang salah tentang kontrasepsi implan (19) menguragi timbulnya persepsi yang salah pada akseptor tentang kontrasepsi implant.

Hasil penelitian menunjukkan bahwa sebagian besar $(51,4 \%)$ memilki pengetahuan yang cukup tentang implan, sedangkan hanya sebagian kecil $(17,1 \%)$ dari akseptor implan yang memilki pengetahuan baik tentang kontrasepsi implan. dalam bukunya, Notoadmojo (2010), berpendapat bahwa Terbentuknya suatu perilaku baru, terutama pada orang dewasa dimulai dari domain kognitif dalam artian seseorang harus tahu terlebih dahulu terhadap stimulus yang berupa materi atau objek dari luar,

Tabel 1. Distribusi Frekuensi Responden di Wilayah Puskesmas Ngagel Rejo (N=70)

\begin{tabular}{|c|c|c|c|c|c|c|}
\hline \multirow{2}{*}{ Karakteristik Responden } & \multicolumn{2}{|c|}{ Non Implan } & \multicolumn{2}{|c|}{ Implan } & \multicolumn{2}{|c|}{ Total } \\
\hline & f & $\%$ & f & $\%$ & f & $\%$ \\
\hline \multicolumn{7}{|l|}{ Usia } \\
\hline$<20$ Tahun & 0 & 0 & 1 & 2,9 & 1 & 1,4 \\
\hline 20-35 Tahun & 13 & 37,1 & 22 & 62,9 & 35 & 50 \\
\hline$>35$ Tahun & 22 & 62,9 & 12 & 34,3 & 34 & 48,6 \\
\hline \multicolumn{7}{|l|}{ Pendidikan } \\
\hline Pendidikan Dasar & 8 & 22,9 & 10 & 28,6 & 18 & 25,7 \\
\hline Pendidikan Menengah & 21 & 60,0 & 23 & 65,7 & 44 & 62,9 \\
\hline Pendidikan Tinggi & 6 & 17,1 & 2 & 5,7 & 8 & 11,4 \\
\hline \multicolumn{7}{|l|}{ Pekerjaan } \\
\hline Tidak Bekerja & 25 & 71,4 & 21 & 60,0 & 46 & 65,7 \\
\hline Bekerja & 10 & 28,6 & 14 & 40,0 & 24 & 34,3 \\
\hline \multicolumn{7}{|l|}{ Paritas } \\
\hline Pripara & 6 & 17,2 & 15 & 42,9 & 21 & 30 \\
\hline Multipara & 25 & 71,4 & 20 & 57,1 & 45 & 64,3 \\
\hline Grande Multipara & 4 & 11,4 & 0 & 0 & 4 & 5,7 \\
\hline
\end{tabular}

Tabel 2. Hubungan Penggunaan Kontrasepsi Implan dengan KIE dan Pengetahauan (N=70)

\begin{tabular}{|c|c|c|c|c|c|c|c|}
\hline \multirow{2}{*}{ Variabel } & \multicolumn{2}{|c|}{ Non Implan } & \multicolumn{2}{|c|}{ Implan } & \multicolumn{2}{|c|}{ Total } & \multirow{2}{*}{ p-value } \\
\hline & f & $\%$ & f & $\%$ & f & $\%$ & \\
\hline \multicolumn{8}{|l|}{ KIE } \\
\hline Kurang & 11 & 31,4 & 1 & 2,9 & 12 & 17,1 & \multirow{3}{*}{0,001} \\
\hline Cukup & 10 & 28,6 & 6 & 17,1 & 16 & 22,9 & \\
\hline Baik & 14 & 40,0 & 28 & 80,0 & 42 & 60,0 & \\
\hline \multicolumn{8}{|c|}{ Pengetahuan } \\
\hline Kurang & 10 & 28,6 & 11 & 31,4 & 21 & 30,0 & \multirow{3}{*}{0,94} \\
\hline Cukup & 18 & 51,4 & 18 & 51,4 & 36 & 51,4 & \\
\hline Baik & 7 & 20,0 & 6 & 17,1 & 13 & 18,6 & \\
\hline
\end{tabular}

Pemberian KIE merupakan suatu pendekatan sehingga, meskipun keputusan dalam memilih jenis kontrasepsi tergantung pada akseptor, namun dengan pemberian KIE yang efektif dan lengkap tentang kontrasepsi akan menumbuhkan pemahaman akseptor tentang kontrasepsi yang baik dan benar sehingga dapat membentuk persepsi positif terhadap penggunaan kontrasepsi implan (20). Namun selama ini, pemberian KIE dilapangan kurang efektif, karena ada beberapa informasi yang kurang tersampaikan dengan baik. Hal ini dikarenakan masih sedikitnya bidan yang memberikan KIE menggunakan media (ABPK), selain itu ramainya pelayanan yang dilakukan oleh bidan menyebabkan waktu untuk pemberian KIE secara lengkap kurang optimal. Namun dengan adanya pemberian KIE atau konseling oleh bidan dapat sehingga akan timbul pengetahuan baru pada seseorang yang kemudian akan timbul respon batin dalam bentuk sikap seseorang tersebut terhadap objek yang telah diketahuinya (21). Dari hasil penelitian dapat disimpulkan bahwa tidak semua responden yang menggunakan implan memilki pengetahuan yang baik tentang kontrasepsi implan. Selain itu, banyak faktor yang mempengaruhi pengetahuan seseorang, seperti usia, pekerjaan, dan lingkungan. Berdasarkan pendapat yang diungkapkan oleh I. Mubarak (2012) bahwa lingkungan berpengaruh terhadap proses masuknya pengetahuan ke dalam individu yang berada dalam lingkungan tesebut, dimana informasi dapat diperoleh dari lingkungan kerja (22).

Hasil analisis penelitian didapatkan nilai $p=0,94$ $(p>0,05)$ yang berarti tidak terdapat hubungan antara pengetahuan dengan penggunaan kontrasepsi 
implant. Nilai OR diperoleh nilai kurang dari 1 dengan CI 95\% pada rentang kurang dari 1 dalam artian CI memuat angka 1, sehingga dapat dianggap bahwa tidak ada beda kejadian penggunaan kontrasepsi implan pada pengetahuan baik, cukup, maupun kurang. Penelitian ini sejalan dengan penelitian yang dilakukan oleh Imroni, (2009) tentang faktor-faktor yang berhubungan dengan penggunaan implan di Desa Parit Kecamatan Indralaya, bahwa tidak ada hubungan antara pengetahuan akseptor tentang implan dengan penggunaan implan, karena penggunaan implan tidak hanya dipengaruhi oleh pengetahuan tetapi juga dipengaruhi oleh ketersediaan alat kontrasepsi dan juga kesadaran untuk menggunakan implan. Meskipun seseorang memilki pengetahuan yang baik tentang kontrasepsi implan, namun jika tidak memilki kesadaran akan pentingnya kontrasepsi yang berjangka panjang dengan effektifitas tinggi maka dia tidak akan memilih kontrasepsi tersebut menjadi pilihan utamanya (18).

Namun hal ini bertolak belakang dengan penelitian Thoyyib, (2013) di BPS Desa Dukun Gresik yang mengungkapkan bahwan terdapat hubungan antara tingkat pengetahuan tentang implan dengan pemakaian kontrasepsi implan, pengetahuan yang baik akan mempengaruhi seseorang untuk memilih kontrasepsi yang tepat dengan didasari oleh pemahaman terhadap manfaat dari kontrasepsi tersebut (23).

Pada dasarnya banyak faktor yang mempengaruhi seseorang dalam berperilaku dan memutuskan suatu hal, pengetahuan bukan merupakan satu-satunya faktor mutlak yang mempengaruhi penggunaan kontrasepsi implan. Banyak faktor-faktor lain yang dapat mempengaruhi perilaku dan sikap seseorang dalam menentukan jenis kontrasepsi yang akan dia gunakan. Pengetahuan yang baik tentang implan tidak cukup mendasari seseorang menggunakan implan, dikarenakan akseptor akan memilih menggunakan kontrasepsi yang nyaman pada diri mereka, sehingga akseptor non implan yang sudah merasa nyaman dengan kontrasepsi sebelumnya akan kembali menggunakan kontrasepsi tersebut. Selain itu, lingkungan juga berpengaruh pada seseorang, dimana pengalaman dari seseorang di lingkungan sekitarnya akan mempengaruhi akseptor dalam memilih jenis kontrasepsi yang akan dia gunakan.

Melalui pemberian informasi dan edukasi kesehatan yang berdasarkan evidence based dan mengandung informasi terkini secara efektif dan efisien, akan memberikan kesempatan pada seseorang untuk memilih jenis metode kontrasepsi yang paling sesuai dengan kondisi dan kebutuhannya (24).

\section{KESIMPULAN}

Terdapat hubungan yang positif antara penggunaan kontrasepsi implan dengan KIE yang pernah didapatkan dari tenaga kesehatan, kualitas dan kejelasan KIE yang diberikan akan menentukan peningkatan penggunaan kontrasepsi implan. Namun tidak ada hubungan antara penggunaan kontrasepsi implan dengan pengetahuan yang dimiliki oleh akseptor. Pengetahuan akseptor dapat lebh ditingkatkan dengan pemberian KIE menggunakan media yang lebih efektif dan efisien.

\section{UCAPAN TERIMA KASIH}

Terima kasih penulis sampaikan kepada semua pihak yang terkait dalam proses penelitian termasuk diantaranya Puskesmas Ngagel Rejo Kota Surabaya dan kader yang telah membantu peneliti serta seluruh responden yang telah berpartisipasi dalam penelitian ini.

\section{DAFTAR PUSTAKA}

1. Didik Budjianto. Profil Kesehatan Indonesia Tahun 2016. Jakarta: Kementrian Kesehatan Republik Indonesia; 2017.

2. Kemenkes RI. Situasi Keluarga Berencana di Indonesia. Pus Data dan Inf Kesehat. 2013;

3. Kemenkes RI. Situasi dan Analisis Keluarga Berencana. Pus Data dan Inf Kementrian Kesehat RI. 2014;

4. Hartanto W. Analisis Data Kependudukan Dan Kb Hasil Susenas 2015. 2016;

5. Andria. Faktor-Faktor Yang Mempengaruhi Rendahnya Pemakaian KB Implan Didesa Margamulya Wilayah Kerja Puskesmas Rambah Samo I. J Matern Neonatal. 2016;2(2):121-8.

6. Nuzula F, Widarini NP, Karmaya M, Nuzula F, Widarini NP, Karmaya M. Faktor-Faktor yang Berhubungan dengan Pemakaian Implan pada Wanita Kawin Usia Subur di Kabupaten Banyuwangi. Public Heal Prev Med Arch. 2015;3:104-11.

7. Gebremariam A \& Addissie A. Knowledge and Perception On Long Acting and Permanent Contraceptive Methods in Adigrat town, Tigray, Northern Ethiopia: A Aualitative Study. Int J Fam Med. 2014;

8. Affandi B. Buku Panduan Praktis Pelayanan Kontrasepsi. Jakarta: Bina Pustaka Sarwono Prawirohardjo; 2014.

9. Trihono, Atmarita, Tjandrarini DH, Irawati A, Utami NH, Tejayanti T, et al. Pendek (Stunting) di Indonesia, Masalah dan Solusi. Lembaga Penerbit Balitbangkes. 2015. 218 p.

10. Salvina, Hasifah SS. Faktor-Faktor Yang Mempengaruhi Rendahnya Minat Untuk Menggunakan Metode Kontrasepsi Hormonal ( Implant ) Pada Akseptor Kb Di Puskesmas KassiKassi Makassar. J e-library Stikes Nani Hasanudin Makasar. 2013;2.

11. Atnafe M, Assefa N, Alemayehu T. Long-acting 
family planning method switching among revisit clients of public health facilities in Dire Dawa, Ethiopia. Contracept Reprod Med. 2016 Sep;1(1):18.

12. Ajong $A B$, Njotang $P N$, Kenfack B, Yakum MN, Mbu ER. Knowledge of women in family planning and future desire to use contraception: A cross sectional survey in Urban Cameroon. BMC Res Notes. 2016;9(1):1-9.

13. Hoopes AJ, Ahrens KR, Gilmore K, Cady J, Haaland WL, Oelschlager AA, et al. Knowledge and Acceptability of Long- Acting Reversible Contraception Among Adolescent Women Receiving School- Based Primary Care Services. 2016;

14. Dinkes. Profil Kesehatan Kota Surabaya Tahun 2016. Surabaya: Dinas Kesehatan Kota Surabaya; 2017.

15. Saifuddin AB. Buku Panduan Praktis Pelayanan Kesehatan Maternal dan Neonatal. Jakarta: Pt Bina Pustaka Sarwono Prawirohardjo; 2010.

16. Pratiwi NL. Pemberdayaan Masyarakat dan Perilaku Kesehatan (Teori dan Praktek). Surabaya: Airlangga University Press; 2013.

17. Ellawela $\mathrm{Y}$ et all. Sexual \& Reproductive Healthcare Contraceptive use and contraceptive health care needs among Sri Lankan migrants living in Australia: Findings from the understanding fertility management in contemporary Australia survey. Sex Reprod Healthc. 2017;12:70-5.

18. Imroni M dkk. Faktor-Faktor Yang Berhubungan Dengan Penggunaan Implan Di Desa Parit Kecamatan Indralaya Utara Kabupaten Ogan Ilir Tahun 2009. 2009;

19. Lasut V dkk. Pengaruh Pendidikan Kesehatan terhadap Pengetahuan PUS Tentang Alat Kontrasepsi Implan di Wilayah Kerja Puskesmas Nuangan Bolaang Mongondow Timur. 2013;

20. Hanum Z dan I. Konseling dan Dukungan Suami dengan Minat Ibu Dalam Pemakaian Kontrasepsi Implan. Lentera. 2014;14.

21. Notoadmojo S. Promosi Kesehatan: Teori dan Aplikasi. Rineka Cipta; 2010.

22. Mubarak I. Ilmu Kesehatan Masyarakat. Jakarta: Salemba Medika; 2012.

23. Thoyyib TB dan YW. Hubungan Antara Tingkat Pengetahuan Tentang Implan dengan Pemakaian Kontrasepsi Implan. 2013;

24. Blumenthal, P.D., Voedisch, A., Danielsson K. Strategies to Prevent Unintended Pregnancy: Increasing Use of Long Acting Reversible Contraception. Hum Reprod Updat. 2011;17. 